\title{
送電線鉄塔の雷撃逆フラッシオーバの予測解析に おける電流波頭長の検討
}

\author{
正 員 有 働 龍 夫 (電中研) \\ 正員松 原 廣 治 (電中研)
}

Examination of Lightning Wave Front Times Which are Adequate on the Estimation of Backflashover of Transmission Line Towers

Tatsuo Udo, Member, Hiroji Matsubara, Member (Central Research Institute of Electric Power Industry)

キーワード：雷撃電流，波頭長，超高圧送電線，鉄塔逆フラッジオーバ，事故実績，EMTP

\section{1. まえがき}

送電線の雷害事故の解析や予測の研究は, 永い歴史 があって, 現在は耐雷設計基準委員会が昭和 46 年, 51 年にまとめた要綱など(1)(2)を基礎として，これに 改良を加えた方法 ${ }^{(3)}$ が多く使われている。1950年代 以降, 国内外で雷撃電流波形の観測が行われ，また 1960 年代後半以降, 日本で $500 \mathrm{kV}$ 二回線送電線が多 数建設されて, 高さ $60 \sim 80 \mathrm{~m}$ の送電線の雷害事故実 績が明らかになってきた (2)(11)。

送電線の雷撃逆フラッシオーバの発生を予測する際 に想定する雷撃電流波頭長は, AIEE 方式(4), ほか では4 $\mu$ sを推奨し，また前記要綱など(1) (3)(9) では2 $\mu \mathrm{s}$ を多用し, EPRI の設哔指針 ${ }^{(10)} は 0.75 \sim 2.5 \mu \mathrm{s}$ (電流 で変化）を推奨している。波頭長 $2 \mu \mathrm{s}$ と $4 \mu \mathrm{s}$ では送電 線の逆フラッシオーバ発生率の予測計算に大きな差異 を生ずる。一方, Berger らの実測(5)で，雷撃電流が 大きくなるほど累積 50\%波頭長が長くなることが明 りょうとなった。

また，著者らは日本で多用されている計算方式(2)(3) では, 架空地線上に落雷点が分散している実態を等価 的に 1/3 1/4 が鉄塔頂に集中落雷し, 残りは逆フラ ッシオーバに関与しないと仮定しており,これは再吟 味を要すると考えた。また，USAで発表された EPRI の設計指針(10)の中で, 雷撃電流波形を等価的 な RAMP 波に換算する計算方式は改良の余地があ る。本論文では，この計算精度を上げ我が国の
$275 \sim 500 \mathrm{kV}$ 二回線垂直配列送電線の事故実績を解析 した結果, 大電流領域 $(70 \sim 150 \mathrm{kA})$ では雷撃電流波 頭長を $4 \mu \mathrm{s}$ 程度で代表させれば, 逆フラッシオーバ 事故実績と整合することがわかった。

\section{2. 雷害事故実績からの検討}

表 1 表 3 に $500 \mathrm{kV}$ 垂直二回線送電線の雷害事故 統計(7)(8)(11) を引用する。夏期雷地域(表 1 )において は, 一線地絡, 多相地絡ともに上, 中, 下相にほほ一 様に分布している。このことは逆フラッシオーバの起

表 $1500 \mathrm{kV}$ 二回線垂直配列, 高高絶縁送電線 の雷害事故実續(11)

Table 1. Lightning performance of $500 \mathrm{kV}$ double-circuit, balanced insulation transmission lines.

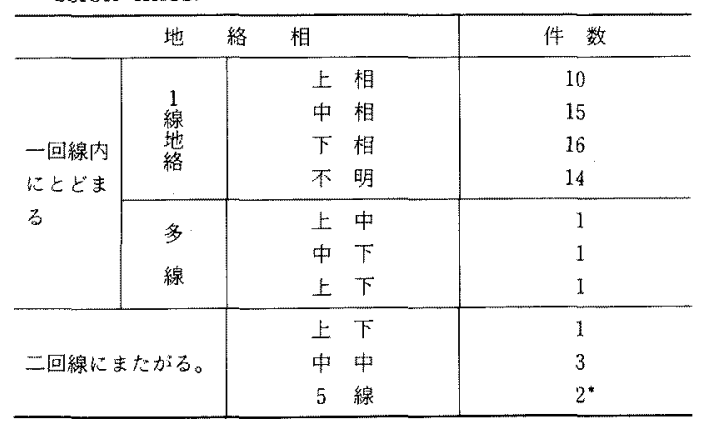

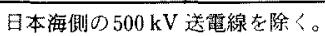

1966年 2 月 1982年 3 月。延心1 $10,577 \mathrm{~km}$ ·年。

*12月に発生。上上中中下。 
表 $2500 \mathrm{kV}$ 二回線重直配列不平衡絶縁送電線 ○雷害事故害續 ${ }^{(8)}(11)$

Table 2. Lightning performance of $500 \mathrm{kV}$ double circuit, unbalanced insulation transmission lines.

\begin{tabular}{|c|c|c|c|}
\hline \multicolumn{2}{|l|}{ 期 間 } & $66 \sim 82$ & '80 ' 85 \\
\hline \multicolumn{2}{|c|}{ 覞測線嗠 $\mathrm{km}$ - 年 } & 2945.9 & 1741.6 \\
\hline \multicolumn{2}{|l|}{ 地絡相 } & 件 数 & 件 数* \\
\hline $\begin{array}{l}\text { 一回線咑 } \\
\text { どまる。 }\end{array}$ & $\begin{array}{l}\text { 上 } \quad \text { 相 } \\
\text { 中 } \text { 柏 } \\
\text { 下 } \\
\text { 不 } \\
\text { 上中明 } \\
\text { 上中相 } \\
\text { 中下相 } \\
\text { 上下相 } \\
\text { 上中下 }\end{array}$ & $\begin{array}{c}3(H)+14(L) \\
4(H)+15(L) \\
10(L) \\
11 \\
2(L) \\
3(L) \\
2(L) \\
1(H \& L)\end{array}$ & $\begin{array}{c}7(L) \\
1(H)+8(L) \\
6(L)\end{array}$ \\
\hline $\begin{array}{l}\text { 一回線にま } \\
\text { たがる。 }\end{array}$ & $\begin{array}{l}\text { 中中相 } \\
\text { 上中下 } \\
\text { 上上中下 }\end{array}$ & $\begin{array}{l}1(H \& L) \\
1(H \& L) \\
1(H \& L)\end{array}$ & $1(H \& L)$ \\
\hline
\end{tabular}

$H$ : 高䋓縁側, $L$ : 低紿縁側

* 全部馥期

表 $3500 \mathrm{kV}$ 垂直二回線配列鉄塔の塔脚接地 抵抗值と事故件数 (8 線路) 冬期雷含含 (11)

Table 3. The distribution of tower footing resistance of eight $500 \mathrm{kV}$ double circuit lines.

\begin{tabular}{c|c|c}
\hline 葌地抵抗 $(\Omega)$ & 鉄塔基数 (基) & 事故件数(件) \\
\hline $0 \sim 5$ & 339 & $23(5)$ \\
$6 \sim 10$ & 665 & $27(5)$ \\
$11 \sim 15$ & 90 & $1(1)$ \\
$16 \sim 20$ & 16 & 1 \\
$21 \sim 25$ & 4 & $1(1)$ \\
$26 \sim 30$ & 2 & $1(1)$ \\
$>31$ & 2 & 0 \\
不明 & & $13(2)$ \\
\hline
\end{tabular}

（）内は二回線にまたがる事故件数で网数

こりやすさが上,中，下相でほぼ同等であることを示し ている。次に, 不平衡絶縁 $500 \mathrm{kV}$ 送電線 (表 2 ) の事 故統計から, 遮へい失敗(導体直撃)によるフラッシオ 一バ発生の確率を推論した。不平衡絶縁線路では 1 線 逆フラッシオーバは低絶緑側に発生するはずであるか ら，表 2 の中で高絶縁側( $H$ で示す)の1線地絡は遮 へい失敗であると推測される。表 2 の左側の㯗では, $2,945.9 \mathrm{~km}$ ・年あたりで7回，士なわ方 0.23 回/ $100 \mathrm{~km}$ ・年, 右側の闌では $1,741.6 \mathrm{~km}$ 年あたりで 1 回，すなわち 0.06 回 $/ 100 \mathrm{~km}$ ・年であり，4倍の差が ある。観測対象の線路こう長，年数が十分でないこ と，また総事故数も左側の欄は2.31 回, 右側の欄は 1.38 回 $/ 100 \mathrm{~km}$ ・年であって, 観測期間中の発雷に差 があると考えられる。左右両欄を加重平均すれば
表 $4275 \mathrm{kV}$ 二回線垂直配列, 高高絶縁送電線 の雷害事故実績 (架空地線 2 条) (2) $^{(2)}$

Table 4. Lightning performance of $275 \mathrm{kV}$ double-circuit, balanced insulation transmission lines.

\begin{tabular}{|c|c|c|c|}
\hline 遮へい角 & $\begin{array}{l}\text { 上相に対し } \\
\text { 中相に対し }\end{array}$ & $\begin{array}{l}14 \sim 19^{\circ} \\
.17 \sim 25^{\circ}\end{array}$ & $\begin{array}{c}6 \sim 13^{\circ} \\
12 \sim 16^{\circ}\end{array}$ \\
\hline \multirow{2}{*}{$\begin{array}{l}\text { 一回線にと } \\
\text { どまる。 }\end{array}$} & $\begin{array}{l}\text { 上相のみ } \\
\text { 中相のみ } \\
\text { 下相のみ }\end{array}$ & $\begin{array}{r}6 \\
22 \\
3 \\
\end{array}$ & $\begin{array}{r}10 \\
18 \\
2\end{array}$ \\
\hline & $\begin{array}{l}\text { 上相を含む } \\
\text { 中相を含む } \\
\text { 下相を含む }\end{array}$ & \multirow{2}{*}{ 件数 7} & \multirow{2}{*}{ 化数 19} \\
\hline $\begin{array}{l}\text { 二回線にま } \\
\text { たがる。 }\end{array}$ & $\begin{array}{l}\text { 上相を企む } \\
\text { 中相を含む } \\
\text { 下相を含む }\end{array}$ & & \\
\hline \multicolumn{2}{|c|}{ 全事故率 $100 \mathrm{~km}$ 年 } & 1.54 & 0.96 \\
\hline
\end{tabular}

0.17 回 $/ 100 \mathrm{~km}$ ・年となる。不平衡絶縁送電線は, 雷 雨の発生が平均的よりかなり多い場所に建設されてい ることを考慮して，表10中に含まれる遮へい失敗は $(0.06 \sim 0.23) \times 2$ (両側回線)を根拠として，0.2 0.3 回 $/ 100 \mathrm{~km}$ ・年であろうと推定した。従って, 表 1 の 中で逆フラッシオーバ発生は $(0.61-0.2 \sim 0.3)=$ $0.41 \sim 0.31$ 回 $/ 100 \mathrm{~km}$ ・年と推定される。

不平衡絶縁線路の逆フラッシオーバは，表 2 の左側 加ら(総事故 68 件) - (高絶緑側 1 線地絡 7 件の 2 倍) $=54$ 件を $2945.9 \mathrm{~km}$ ・年で除した 1.8 回 $/ 100 \mathrm{~km} ・$ 年 と, 表 2 の右欄加ら(総件数 24 件) - (高絶縁側 1 線地 絡 1 件の 2 倍 $)=22$ 件を $1741.6 \mathrm{~km}$ ・年で除した 1.3 回/ $100 \mathrm{~km} \cdot$ 年が発生実績と推定される。

表 $4 k 275 \mathrm{kV}$ 垂直二回線配列送電線の雷害事故統 計を引用する(2)。1 線地絡は中相の事故率が上相，下 相に比べて著しく高い。一方，多線地絡は上・中相に はほぼ同等に発生している。この統計から見て,上・ 中相の逆フラッシオーバの発生しやすさは同等であ り，中相で 1 線地絡が多発しているのは，進へい失敗 に起因するものであると推論できる。表 4 で，中相の 1 線逆フラッシオーバ発生率を上相と同等であるとす ると, 表 4 の左欄の全逆フラッシオーバ発生率注(1 線逆フラッシオーバ 15 件と多線逆フラッシオーバ 7 件) 0.89 回 $/ 100 \mathrm{~km}$ ・年と推論される。表 4 の右欄で は, 同様に全逆フラッシオーバ発生率は(1 線逆) ラッシオーバ22件と多線逆フラッシオーバ19件） 0.80 回 $/ 100 \mathrm{~km}$ ・年と推論される。

また，1980〜85 年の全国統計 ${ }^{(8)}$ によると，275 kV 2 回線送電線の雷害事故率は 0.79 回 $/ 100 \mathrm{~km}$ •年(架 空地線 1 条の区間も含む)である。この中から架空地 
線 1 条の区間(全調査対象の14\%)を除き，かつ遮へ い失敗による 1 線地絡を推定して除くと, 逆フラッシ オーバ発生率は約 0.64 回 $/ 100 \mathrm{~km}$ ・年と推論される。

\section{3. 事故率予測計算との対比}

鉄塔逆フラッシオーバを発生させるに足る雷撃電流 は次式で計算できる゙(1)(2)。

$$
I_{L}=\frac{k / \alpha \cdot V-E_{p}}{(K-C) Z_{T}}
$$

ここで，

$I_{L}:$ 鉄塔逆フラッシオーバが発生する平均電流。

$Z_{r}$ : 塔頂に単位のサージ電流が侵入したときに塔

頂の電位上昇を与える等価インピーダンス。

$K:$ 上, 中, 下腕金の電位上舁と塔頂電位上昇の 比。塔頂の波形と, 上, 中, 下腕金電位の波形は 相似ではない(14)。

$C$ : 架空地線 $(2 \sim 3$ 条一括 $)$ と本線との結合率。衡 撃コロナによりCが増大する。Cの增大は逆つ ラッシオーバを減少させることとなる。井上の実 規模実験(13)参照すれば，架空地線の電位が 1.8 MVあたりでCが2〜3\%増大, $1 \mathrm{MV}$ あたりで $C$ が約 1.5\%増大する。本論文では, 逆フラッシ オーバ発生率が若干過大に算定される傾向があっ ても論旨に差し支えないことまた架空地線 2 条 と本線の間のコロナによるCの増大について夷 規模実験結果がないことなどから，コロナによる Cの増大に詳しく立入らないで, 表 6 の $(K-C)$ を想定した。

$E_{p}$ ：雷撃瞬時の交流電圧值。2 $75 \sim 500 \mathrm{kV}$ 垂直配 列送電線は, 線下地表面の静電誘導電圧を緩和す るため逆相配列を採用していることが多い。この ため, 交流の二相の電圧のうち雷と逆極性で電圧 が大きいほうの相が逆フラッシオーバを発生しや すい。 $A$ と $C^{\prime}$ が上相, $C$ と $A^{\prime}$ が下相のとき, $A$ または $A^{\prime}$ 相が支配要因である位相は $1 / 6 \pi$ $\sim 7 / 6 \pi$ で

表 5 鉄塔高さに対方る補正係数の試算 Table 5. Height correction factor from $66 \mathrm{kV}$ Kinugawa Line to 275 and $500 \mathrm{kV}$ lines.

\begin{tabular}{c|c|c|c|c|c}
\hline & $H_{s}$ & $W$ & $R$ & $2 R+W$ & 比 \\
\hline 鬼怒川線 & 15.3 & 5.7 & 86 & 178 & 1.00 \\
\hline $275 \mathrm{kV}$ & 35.7 & 8.5 & 144 & 297 & 1.67 \\
\hline $500 \mathrm{kV}$ & 65.7 & 21 & 209 & 440 & 2.47 \\
\hline
\end{tabular}

$$
\sqrt{2} / \sqrt{3} \cdot E \frac{1}{\pi} \int_{1 / 6 \pi}^{7 / 6 \pi} \sin \theta d \theta=0.55 \sqrt{2} / \sqrt{3} \cdot E
$$

残りの時間は $C$ または $C^{\prime}$ 相が支配要因となるので

$$
\begin{aligned}
& \sqrt{2} / \sqrt{3} \cdot E \frac{1}{\pi} \int_{7 / 6 \pi}^{13 / 6 \pi} \sin (\theta-4 / 3 \pi) d \theta \\
& \quad=0.55 \sqrt{2} / \sqrt{3} \cdot E
\end{aligned}
$$

$B, B^{\prime}$ 相は平均すると0となる。従って， $E_{p}$ とし ては, $0.55 \sqrt{2} / \sqrt{3} \cdot E$ を採用した。

$\alpha:$ 気象条件による絶縁耐力低下係数。表 1 は夏期 雷による事故が大部分であるので, 気温上昇と送 電線経過地の平均的な標高を考えて, $\alpha=1.1$ と 仮定した。

$k$ :上, 中, 下相のがいし間に加わる電圧波形に対 するフラッシオーバ電压の(標準インパルスを 1 としたときの)上昇係数。本論文では, フルスケ ールギャップによる実験結果を引用して下記を用 いた ${ }^{(12)}$ 。 $2 \times 5 \mu \mathrm{s}$ 波には $1.25,4 \times 10 \mu \mathrm{s}$ 波には

$1.18 ， 6 \times 20 \mu \mathrm{s}$ 波には 1.12 。

$V:$ がいし装置の $1 \times 50 \mu \mathrm{s}$ 波に対する $50 \%$ フラッ

シオーバ電圧(表 6 にVの例を示す)。

鉄塔逆フラッシオーバの発生を解析するには，厳密 には鉄塔を 4 段モデルで, 電線を多相モデルで構成 し, 上, 中, 下相のがいし間に加かる電圧波形を求め なけ机ばならないが，鉄塔の塔脚接地抵抗，高さ，鉄 塔内サージ伝搬特性，雷撃点などにより膨大な組合せ があることになる(14)。本論文は，事故統計を説明で きる雷撃電流波䫒長を諭ずることを目的としているの で，必要かつ十分な範囲で計算を行うこととする。

〈3・1〉鉄塔電位上昇の計算波頭長 $6 \mu \mathrm{s}$ まで計 算するため，図1のように6 径間を含むモデル送電線 で，RAMP波が塔頂に侵入したときの塔頂電位上昇 を $\operatorname{EMTP}^{(20)}$ で計算し図 2〜図 3 に示す。鉄塔サージ インピーダンスは $100 \Omega$, 塔脚接地抵抗は $5 \sim 30 \Omega$ と した。鉄塔内サージ伝搬速度は鉄塔内サージ減衰との

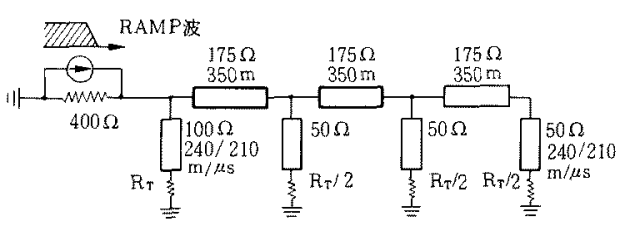

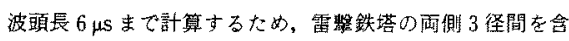
わた。鉄塔，架空地緗のサーシ伝搬損失を模挍するため， 片道伝搬媵の波高値を減喜分だけ低減ざせいる

図 1 鉄塔頂電位上昇計算回路

Fig. 1. A model circuit adopted for calculation of the tower top voltage rise. 
組合せが $Z_{r}$ を文配するので，両者を個別に論ずるこ とは本論文で必要ではない。一例として図 $2 て ゙ ， R_{T}$ $=10 \Omega, T_{r}=2 \mu \mathrm{s}$ のき, 高さ $70 \mathrm{~m}$ の鉄塔に扔いて 次の組合せはいずれも同一の $Z_{r}(36.7 \Omega)$ を与える。

サージ伝搬速度 $210 \mathrm{~m} / \mu \mathrm{s}$, 減衰片道 0.248

$$
\begin{array}{ll}
240 & 0.270 \\
280 & 0.289
\end{array}
$$

〈3・2〉 がいし間電圧と塔頂電圧の比 鉄塔が高 くなることは，下腕金と大地間の距離が增すことを意 味するから，(1)式のうちで $K ， C$ ともに增すこと になる。かつ，腕金のサージ電位上昇波形は塔頂の波 形と相似ではないので(14)，本論文では $(K-C)$ が最 も大きい相に扔いて表6のようになるものとして計算 した。〈4・2〉節に詳述するように，多数の実測や解析

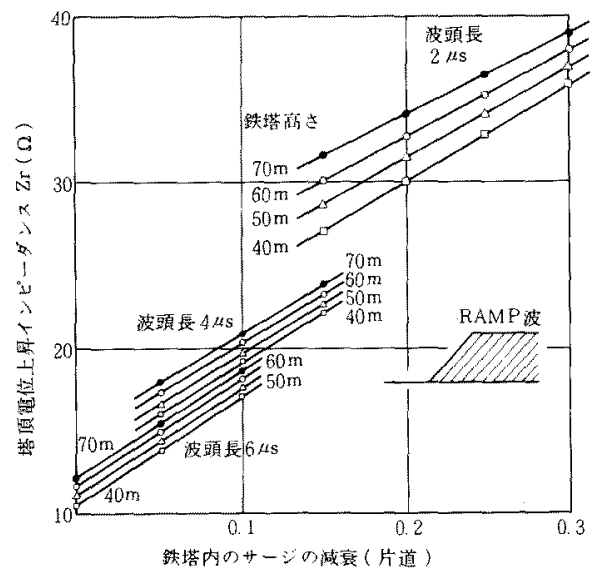

RAMP 波，波尾舆 $\infty$ ，波䫒長は2，4，6 $\mu$ 。 $R_{T}=10 \Omega$ 。 サージ它嘚速度 $210 \mathrm{~m} / \mu \mathrm{s}$ で表示

図 2 鉄塔内のサージの減衰と, 鉄塔頂電位 上昇を与えるインピーダンス $Z_{r}(\Omega)$

Fig. 2. Relations between the calculated tower top voltage rise $\left(Z_{r}\right)$ and attenuation of surge current along the steel tower, dependent on wave front time.
例は大部分この範囲にあるが，多少この範囲を超えて も本論文の目的には差し支えない。

〈3・3〉雷撃電流の累皘頻度 IKL 屿每年, また 数十年周期で入幅に変動する(n。本論文では, 昭和 20 年代後半から 30 年代前半に鬼怒川線でIKLが $30 \sim 35$, 昭和 40 年代後半から 50 年代に $500 \mathrm{kV}, 275$ $\mathrm{kV}$ 線路のある地域の平均が $15 \sim 20^{(2)}, 500 \mathrm{kV}$ 不平 衡絶緑線路のある地域は平均より若干高くて 20〜25(2)であったと仮定した。対地雷撃数は文献 （6）に㭁いて IKLに比例する説と，IKLの1.3烡に 比例する説とが並記されている。鬼怒川線, 超高圧以 上のある地域の平均, $500 \mathrm{kV}$ 不平衡絶緑地域の落雷

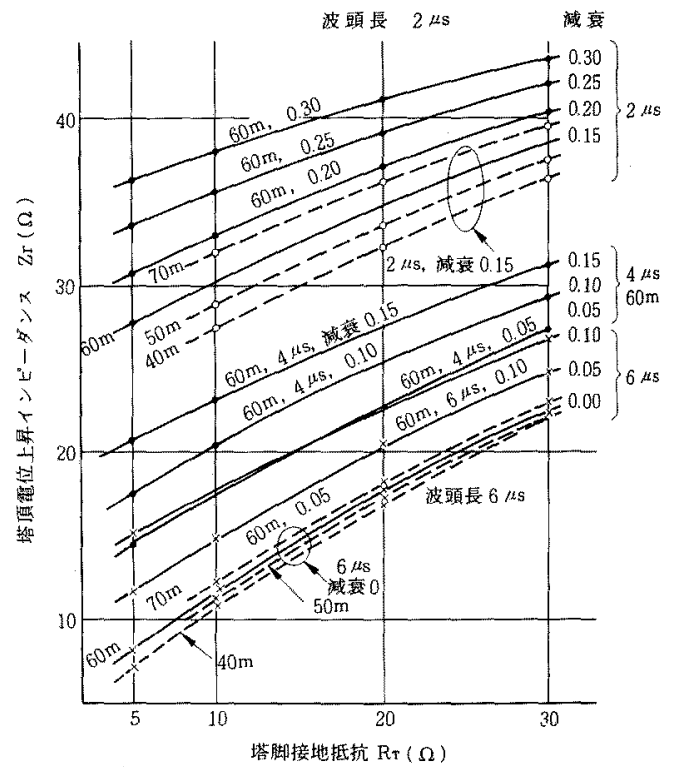

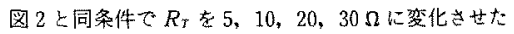

図 3 塔脚接地抵抗と鉄塔頂電位上昇を 与えるインピーダンス $Z_{r}(\Omega)$

Fig. 3. Relations between the calculated tower top voltage rise $\left(Z_{r}\right)$ and tower foot-

\begin{tabular}{|c|c|c|c|c|c|c|c|c|c|}
\hline \multirow{3}{*}{$\begin{array}{l}\text { 電 } \text { 压 } \\
(\mathrm{kV})\end{array}$} & \multirow{3}{*}{ 線路絶粶方式 } & \multirow{3}{*}{$\begin{array}{c}50 \% \\
V \\
(\mathrm{kV})\end{array}$} & \multirow{3}{*}{$\begin{array}{l}\text { 鉄塔高 } \\
\text { サージ伝搬 } \\
\text { 速 度 }\end{array}$} & \multirow{3}{*}{$\begin{array}{c}\text { 波頭長 } \\
\\
(\mu s)\end{array}$} & \multirow{3}{*}{ 鉄塔内減意 } & \multicolumn{4}{|c|}{ 塔脚接地抵抗 } \\
\hline & & & & & & \multicolumn{2}{|c|}{$R_{T}=10 \Omega$} & \multicolumn{2}{|c|}{$R_{T}=20 \Omega$} \\
\hline & & & & & & $K-C$ & $z_{r}$ & $K-C$ & $Z_{r}$ \\
\hline \multirow{3}{*}{500} & 平 衡 & 2,170 & \multirow[t]{2}{*}{$70 \mathrm{~m}$} & 2 & 0.27 & 0.53 & 36.7 & 0.55 & 40.0 \\
\hline & & & & 4 & 0.18 & \} & 25.0 & s & 29.4 \\
\hline & 不平衡 & 1,620 & $240 \mathrm{~m} / \mu \mathrm{s}$ & 6 & 0.09 & 0.58 & 17.3 & 0.60 & 22.3 \\
\hline \multirow{3}{*}{275} & \multirow{3}{*}{ 平 衡 } & \multirow{3}{*}{1,250} & \multirow[t]{2}{*}{$40 \mathrm{~m}$} & 2 & 0.15 & 0.48 & 27.3 & 0.51 & 32.2 \\
\hline & & & & 4 & 0.10 & 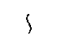 & 19.0 & \} & 24.2 \\
\hline & & & $210 \mathrm{~m} / \mu \mathrm{s}$ & 6 & 0.05 & 0.56 & 14.1 & 0.59 & 19.7 \\
\hline
\end{tabular}
ing resistance $\left(R_{T}\right)$.

表 6 逆フラッシオーバ発生頻度の計算に採用したパラメータ

Table 6. Parameters adopted for the study of backflashover probability. 
表 7 試算に採用した雷撃電流累積頻度分布 Table 7. Cumulative probability of lightning current adopted for the calculation.

\begin{tabular}{|c|c|c|}
\hline \multirow{2}{*}{$\begin{array}{c}\text { 䨳謷琵流 } \\
\text { (kA) }\end{array}$} & \multicolumn{2}{|c|}{ 落雷数 $/$ 年. $100 \mathrm{~km}$} \\
\hline & AIEE & 鬼怒川線 \\
\hline 49.5 超 & 6.22 & 7.2 \\
\hline 63.4 超 & 3.11 & 4.9 \\
\hline 81.6 超 & 1.55 & 2.6 \\
\hline 111.0 超 & 0.62 & 1.25 \\
\hline 134 超 & 0.31 & 0.70 \\
\hline 158 超 & 0.16 & 0.45 \\
\hline
\end{tabular}

頻度の比は（i IKLの上の比 $(1: 0.57: 0.71)$, (ii) IKLの下の比 $(1: 0.5: 0.66)$, (iii) IKLの上の 1.3 乗の比 $(1: 0.48: 0.65)$, (iv) IKLの下の 1.3 乗の比 (1:0.41:0.59)で四者はいずれも大きな差がないの で，四者を算術平均すると，1：0.49:0.65となる。 これから, 表 6 の鬼怒川線頻度に比して全国平均は $1 / 2$, 不平衡絶縁 $500 \mathrm{kV}$ は平均 $2 / 3$ を仮定して事故 発生率を予測した。

〈3.4〉雷擊点の分布 鉄塔頂に半数, 径間中央 に半数がそれぞれ集中して落雷するものと仮定した $(\langle 4 \cdot 3\rangle$ 節に詳述する)。

〈3.5〉雷撃頻度の鉄塔高補正鬼怒川線は鉄塔 高さが $16 \mathrm{~m}$ であるので, $500 \mathrm{kV}$ 線路(鉄塔高さ 70 m)の雷撃頻度に換算するために, Erikssonの方法(6) を使用した。これは，送電線に対する下向き雷撃の頻 度が $(2 \mathrm{R}+\mathrm{W})$ に比例するものとしている。

ここで，R:等価吸引半径 $16.3 \mathrm{Hs}^{0.61}$ $(\mathrm{m}), H_{s}$ : 送電線の有効高さ。鉄塔の高さ から電線のたわみ度の $2 / 3$ を差し引いたも

の, $W:$ 送電線路の実効幅 $(\mathrm{m})$

鉄塔高補正係数は表 5 のように試算される。

表60ようなパラメータを用いて, 逆フラッシオー バを発生させるに足りる電流を計算した。数值の例を 下記に示す。

$500 \mathrm{kV}$, 鉄塔高 $70 \mathrm{~m}$, 塔脚接地抵抗 $10 \Omega$,

平衡高絶縁, 波頭長 $2 \mu \mathrm{s}$ で $107 \mathrm{kA}, 4 \mu \mathrm{s}$ で $151 \mathrm{kA}, 6 \mu \mathrm{s}$ で $189 \mathrm{kA}$

$275 \mathrm{kV}$, 鉄塔高 $40 \mathrm{~m}$, 塔脚接地抵抗 $10 \Omega$, 平衡絶緑, 波頭長 $2 \mu \mathrm{s}$ で $91 \mathrm{kA}, 4 \mu \mathrm{s}$ で 115 $\mathrm{kA}, 6 \mu \mathrm{s}$ で $136 \mathrm{kA}$

これらの電流值と表 7 の雷撃電流頻度分布から, 逆 フラッシォーバ発生頻度を計算した結果を図 4〜図 5 に示す。表 3 から $500 \mathrm{kV}$ 送電線で雷害事故を発生し た鉄塔の大部分は, 塔脚接地抵抗が $10 \Omega$ 以下であっ た。図 4 から, 事故実績をよく説明できる雷擊電流波

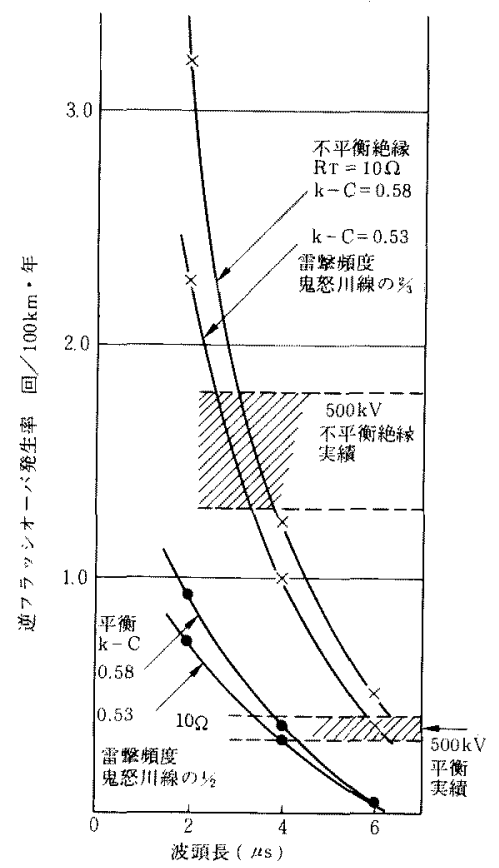

図 4 波頭長と逆フラッシオーバ発生率の 関係 $\left(500 \mathrm{kV}, R_{T}=10 \Omega\right)$

Fig. 4. Relations between wave-front time and the calculated probability of backflashover, compared with actual performance of $500 \mathrm{kV}$ double circuit lines.

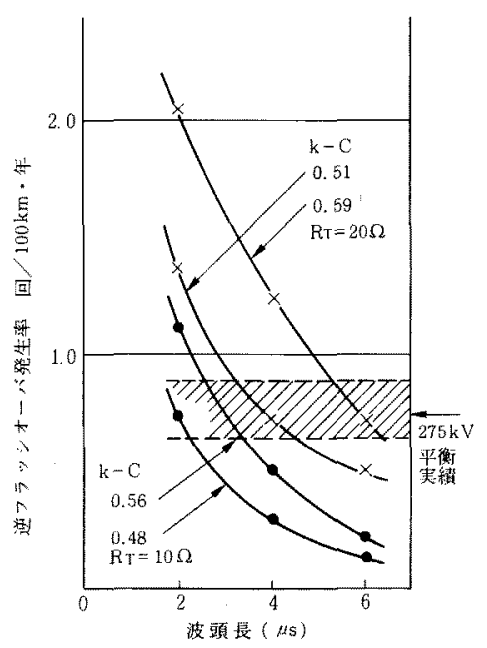

図 5 波頭長と逆フラッシオーバ発生率の 関係 $(275 \mathrm{kV}$, 平衡絶縁)

Fig. 5. Similar characteristics to Fig.4 for $275 \mathrm{kV}$ lines. 
頭長牥約 $4 \mu \mathrm{s}$ (RAMP 波表示)である。275 kV 送電線 は，塔脚接地抵抗が $10 \sim 20 \Omega$ の間に分布している(16) ので事故実績をよく説明できる雷撃電流波頭長は, 図 5 から約 3.5〜 4 $\mu$ 常る。

\section{4. 採用したパラメータの検討}

〈4・1〉鉄塔高さの補正係数 〈3・5〉節の上うに $500 \mathrm{kV}$ で2.47を採用した。最も小さいものは， $H^{0.5}$ に比例とする説(2)で 2.03 となり，最も高いものは $\left(W+4 H_{s}{ }^{1.09}\right)$ に比例するとする説(10)で4.65になる。 逆フラッシオーバ発生率の計算檤が本論文の試算より $4.65 / 2.43 \fallingdotseq 2$ 倍も石きくなと, 波頭長 $2 \mu \mathrm{s}$ でま すます説明しにくい。

\section{〈4・2〉本論文で採用した $(\boldsymbol{K}-\boldsymbol{C}) \boldsymbol{Z}_{\mathrm{r}}$ の妥当性}

(1)式の待母は $(K-C) Z_{r}$ である。 $500 \mathrm{kV}$ 夷規模 送電線で最近実測された結果(14)(18) と本諭文の方式で 計算した值との比較を図 6 に示す。文䓟(14) の夷測値 は本論文の方法による計算值とほほ一致する。文献 (18)の奏測值は許算値より約 10\%低い。文献(18)の 著者らは実测値と鉄塔の各種モデルによる解析の比較 を試み，その著者らが最も適切であるとした 4 段鉄塔 モデルによる $(K-C) Z$ ，計算值は実測值を約 $5 \%$ 上 回っている。本論文の方式による計算結果は, 文献 (18)の著者らの解析とよく一致している。これらの実 測との対比から, 本論文で採用した $(K-C) Z_{r}$ は妥 当な值であると考える。

$275 \mathrm{kV}$ 送電線に扣いて, 架瑩地線を取付けた状態

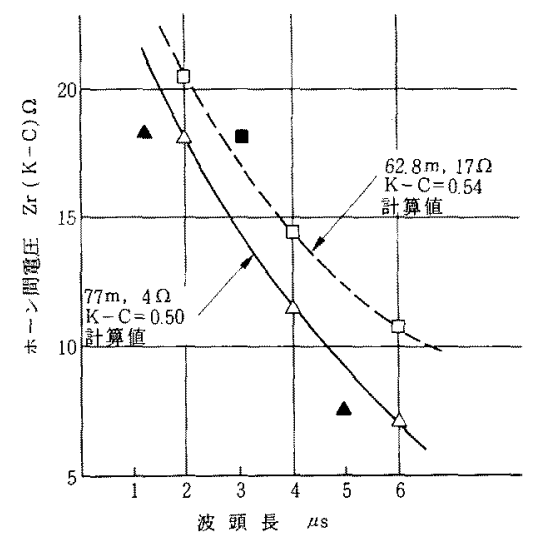

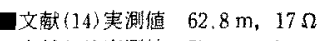

A文献(18)赛測值 $77 \mathrm{~m}, 4 \Omega$

図 6 ホーン間電圧の実測值と計算値の比較 (架空地線 2 条, $240 \mathrm{~m} / \mu \mathrm{s}$ )

Fig. 6. Comparison of field test results and estimated surge voltage across an insulator string.
の奉測值がないが，鉄塔単体の実剆值が多数あるの で(1)，鉄塔サージインピーダンスは $100 \Omega$, 伝搬速度 は $210 \mathrm{~m} / \mu \mathrm{s}$ とし, 伝搬損失は $500 \mathrm{kV}$ 鉄塔の伝搬損 失を高さ比例になるものと推論して許算した。

〈4・3〉落雷点の分布鉄塔加ら離れた架空地線 上に落雷があったときは，至近鉄塔頂の電位上昇は， 鉄塔頂直撃の場合に比べて小さくなる。雷撃点と鉄塔 頂の距離 $(L)$ と, 同一雷撃電流に対する鉄塔頂電位 上昇の関係を図 70 計算回路で求めた。鉄塔高さ $80 \mathrm{~m}$ (伝搬速度 $240 \mathrm{~m} / \mu \mathrm{s}$ ) と $40 \mathrm{~m}$ (同 $210 \mathrm{~m} / \mu \mathrm{s}$ ), 架 空地線 1 条でそのサージインピーダンスは $500 \Omega$, 架 空地線上のサージ減衰は $0.15 / 350 \mathrm{~m}$, 雷撃電流波頭

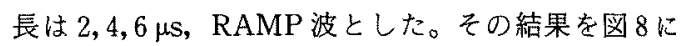
示す。鉄塔高, 波頭長, 鉄塔内サージ減衰のパラメー

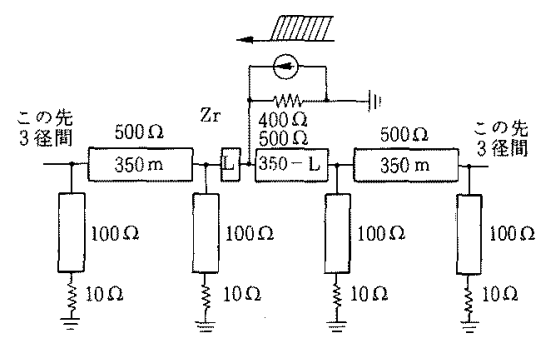

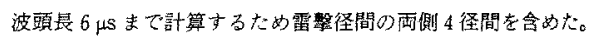
図 7 架空地線径間落雷のときの至近鉄塔頂 電位上昇計算回路

Fig. 7. A model circuit to calculate the tower top voltage rise when a lightning stroke hit the shielding wire.

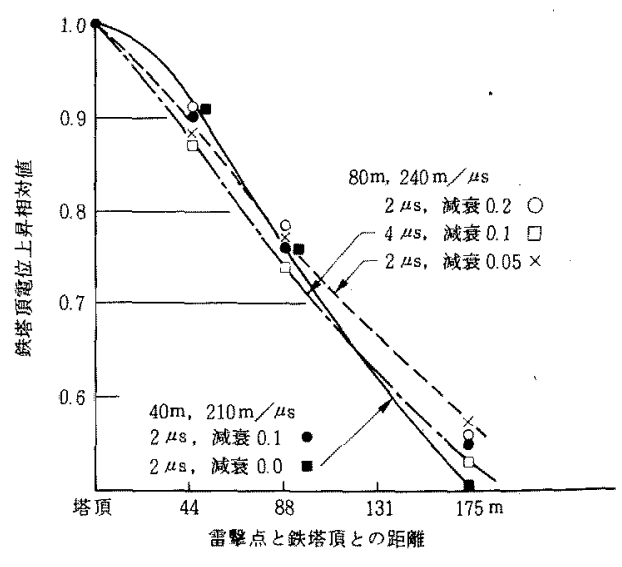

減衰は鉄塔内片道のサー・゙伝搬隇衰

図 8 架空地線径間落雷点の位㯰と鉄塔頂電位 上昇の相対值 (塔頂雷搫のときを 1 とする)

Fig. 8. Relation between the tower top voltage rise and the distance from the tower to the hit point on the shielding wire. 


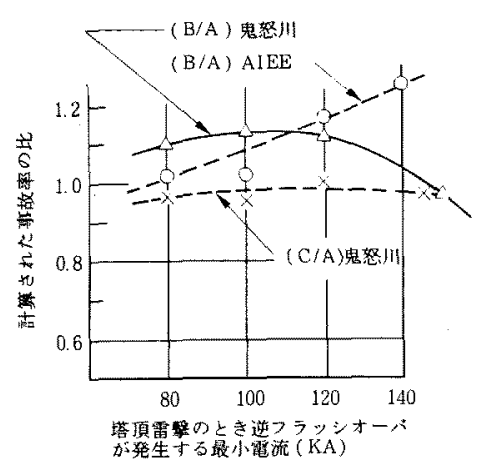

$A:$ 架空地線上に均等に落雷

$B$ : 全雷整の $1 / 2$ が鉄塔頂に，残り $1 / 2$ は径間中央に集中し て落雷

$C:$ 全雷慗の $1 / 2$ が鉄塔項に䔩中して落雷し, 残りは鉄塔送 フラッシオーパに関与しない上仮定

図 9 雷撃点の分布の仮定と逆フラッシオーバ 事故率計算值との関係

Fig. 9. The comparison of back-flashover probabilities which are calculated under three different assumptions on the distributions of lightning stricken points along the shielding wire.

夕の変化があっても，ほ涩類似の傾向を示す。架空地 線上に均等に落雷があると仮定したときの鉄塔逆フラ ッシオーバ発生率を $A$ とする。架架地線と鉄塔頂の 全落雷の $1 / 2$ が鉄塔頂に集中し, 残り $1 / 2$ 㳗間中央 に集中して落雷したものと仮定したときの鉄塔逆フラ ッシオーバ発生率を $B$ とする。

適切な比は鉄塔逆フラッシオーバが発生する最小雷 擊電流值と採用する雷撃電流頻度分布によって変化す るが，図9のように，鬼怒川線頻度のとき $B / A$ は扔打 よそ1.1となる。実際は架空地線上に均等に落雷するの ではなく，電線のたわみ度のため鉄塔近辺のほうがや や密になるとする考方方(10)もあるので，本論文で図 9 のBを採用して試算したことは適切であると考える。

雷撃電流の平均波頭長を $2 \mu \mathrm{s}$ と仮定した計算值と 事故実績を合せるために $\langle 4 \cdot 1\rangle \sim\langle 4 \cdot 3\rangle$ 節を調整して希 望の事故率に合せることもできないわけではないが， 次章の実測結果と著しいかい離を生ずることになる。

\section{5. 雷擊電流波形の実測結果との対比}

独立高鉄塔で夏期雷を実測し，かつ上向きのリーダ を伴う落雷を分別しているものは BergerのSan Salvatore の実測(5)である。

Bergerの実測結果をAndersonらが解析した結 果 ${ }^{(6)}$ は, 負極性第一雷撃について

$$
\begin{array}{ll}
S_{30}=3.2 I^{0.25}(\mathrm{kA} / \mu \mathrm{s}) & \left(\sigma_{s / I}=0.61\right) \\
S_{m}=3.9 I^{0.55}(\mathrm{kA} / \mu \mathrm{s}) & \left(\sigma_{s / I}=0.54\right) \\
I(50 \%)=31.1 \mathrm{kA}, \quad I(5 \%)=68.5 \mathrm{kA}
\end{array}
$$

負極性第二雷撃以降については図 10 の注参照。 ここで， $S_{30}$ ：波高値の $30 \%$ と $90 \%$ の点を結 ぶ直線の傾斜 $(\mathrm{kA} / \mu \mathrm{s}), S_{m}$ : 波頭部の最大 の電圧上昇率 $(\mathrm{kA} / \mu \mathrm{s})$

超高圧以上の送電線で逆フラッシオ一バを発生させ るには，第二雷揧以降は電流值が小さすぎる。第一雷 撃快, 電流值が大きくなるほど波頭長が長くなり， $100 \mathrm{kA} て ゙ は S_{30}$ が $10.1 \mathrm{kA} / \mu \mathrm{s}$ にずない。

Berger の実測結果に上る代表的波形は図 11 右上の ようなもので, CIGRE 波と称される(6)(14)。CIGRE 波 の規約波頭長は $1.67 T_{30}$ である。

鉄塔頂電位上咞を与えるインピーダンス $Z_{r}$ を CIGRE 波とRAMP波で比較したものが図11であ り，CIGRE 波と同等の $Z$ r 者える RAMP 波の波頭 長は, CIGRE波の 1.0 0.75である。雷撃電流 100 $\mathrm{kA}$ では, 図 10 から $S_{30}$ は $10.1 \mathrm{kA} / \mu \mathrm{s}$, 従って CIGRE 波の規約波頭長は $9.9 \mu \mathrm{s}$, こと同等の $Z_{r}$ を与元るRAMP波の波頭長は図 11 から $6 \mu$ 上りは 大きい。

Bergerらの実測を総括すれば，(i)電流波頭長は 電流波高値と密接な相関があり, 電流が大きくなると 波頭長が長くなる，(ii) $70 〜 150 \mathrm{kA}$ というような大 電流については, 平均的な波頭長は等価 RAMP 波で $7 \sim 8 \mu \mathrm{s}$ となるはずである。

Berger らの寒测は, 電流波䪶長と電流波高值は顕 著な相関が認められるから，電圧が低い $(66 \sim 110 \mathrm{kV}$ など)送電線の逆フラッシオーバは電流波頭長 $2 \mu \mathrm{s}$ と 仮定すればよく説明できるとする経験に基づけば，超 高圧以上の送電線で逆フラッシオーバを発生させる電 流領域 $(70 \mathrm{kA}$ 以上)では, 中心的な波頭長は $2 \mu \mathrm{s}$ よ りかなり長いはずである。仅に第 4 章で論述したよう にパラメータを組み合せて超高圧以上でも波頭長 $2 \mu \mathrm{s}$ で整合させても，それは Bergerらの実測によって示 された雷撃電流值と電流波頭長に著しい相関がある事 実と整合しない。

\section{6. 波頭長が $2 \mu \mathrm{s}$ であると仮定した文献と 異なる結論を得た原因}

文献 (2)，(3)は，鉄塔逆フラッシオーバに関与する 雷撃比率を過小に見積もっている。文献 ( 2 )p. 208に は, 雷撃電流波頭長を $2 \mu \mathrm{s}$ に固定して雷害事故率計 算值を逆フラッシオーバ事故実績と整合させるために 


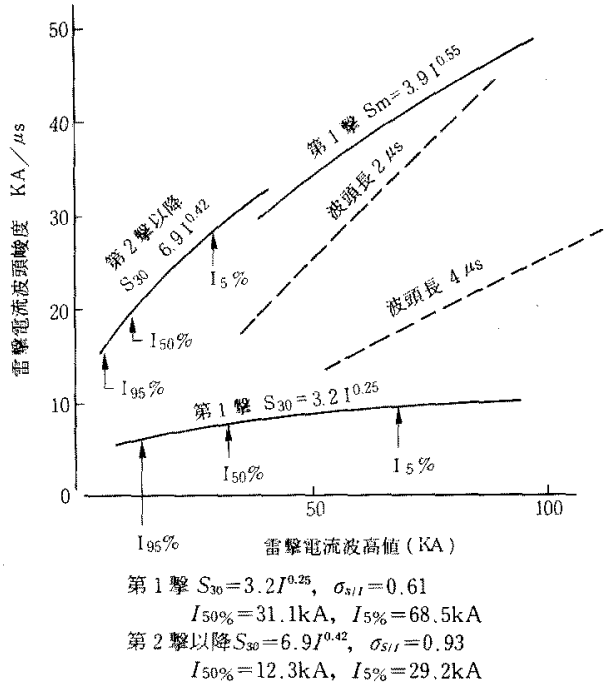

図 10 Berger $の$ 雷撃電流と波頭しゅん度 実測值

Fig. 10. Relation between the wave-front steepness $\left(S_{30}, S_{m}\right)$ and lightning current amplitude, measured by Berger.

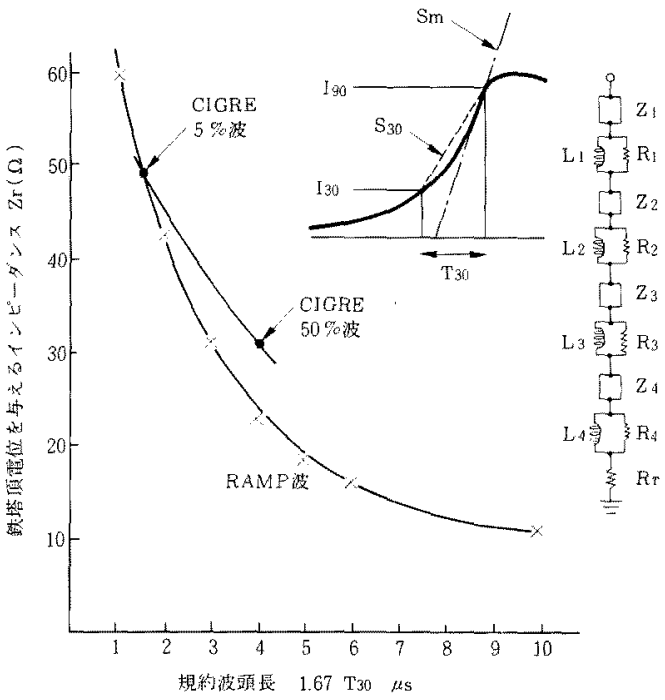

$Z_{1}=7.5 \mathrm{~m}, 220 \Omega, Z_{\mathrm{z}}=Z_{3}=14.5 \mathrm{~m}, 220 \Omega$

$Z_{4}=43 \mathrm{~m}, 150 \Omega$, サージ伝搬速度 $300 \mathrm{~m} / \mu \mathrm{S}$

$L_{1}=5.35 \mu \mathrm{H}, L_{2}=L_{3}=10.34 \mu \mathrm{H}$

$L_{4}=17.74 \mu \mathrm{H}, \quad R_{1}=10.09 \Omega, \quad R_{2}=R_{3}=19.5 \Omega$

$R_{4}=33.5 \Omega, R_{T}=10 \Omega$, 鉄塔高 $79.5 \mathrm{~m}$, 经闆 $350 \mathrm{~m}$, 電線八

相七ミりアンモデルか

信頼時闑 $11.7 \mu \mathrm{s}$

図 11 CIGRE波とRAMP波による 塔頂電位上昇の差

Fig. 11. Comparison of the tower top volt. age rise caused by RAMP waves and CIGRE waves.
は, 鉄塔頂への雷䈲比率を $1 / 3$ とし, 残りは鉄塔逆つ ラッシオーバに関与しないと仮定することが必要であ るとしている。文献 (3)では鉄塔頂への雷撃比率を $25 \%$ と, 残りは鉄塔逆フラッシオーバに関与しない と仮定している。ちなみに文献(1)では鉄塔頂へ $50 \%$ ，文献 $(9)$ ，（10）では鉄塔頂へ $60 \%$ とし，残り は逆フラッシオーバに関与しないと仮定している。こ の見解の差は, 本稿の図 7 図 9 のように, サージの 往復反射の計算結果で解明した。そのうえ, 鉄塔近辺 は径間中央よりも架空地線地上高がたわみ度相当分だ け高いから，図 9 の棓算結果よりも更に鉄塔頂落雷頻 度が高くなる傾问があるう。從って，〈4・3〉節の結果 または文献(1)，（9），(10)の仮定のほうが, 文献 (2)，(3)の仮定より合理的である。

文献 (10)では，雷撃電流波頭の最大 $d I / d t$ と同一し ゆ人度の RAMP波を使えば実用上十分であるとして いる[文献(10) p. 550]。例えば，電流の波頭しゅん度 は $50 \mathrm{kA}$ で約 $30 \mathrm{kA} / \mu \mathrm{s}, 100 \mathrm{kA}$ で約 $50 \mathrm{kA} / \mu \mathrm{s}, 200$ $\mathrm{kA}$ で約 $70 \mathrm{kA} / \mu \mathrm{s}$ 適切であるとしている(同 $\mathrm{p}$ 552)。すな⿰ち，この文献では図 10 , 図 11 の $S_{m}$ と ほ㴗同一しゅん度の RAMP 波を使えば契用上等洒て あるとしている。例えば，図 10 に扔いて電流 $50 \mathrm{kA}$ に対応する最大波頭しゅん度 $\left(S_{m}\right)$ は約 $30 \mathrm{kA} / \mu \mathrm{s}$,

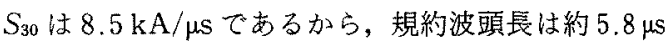
である。図 11 から，規約波頭長約 $5.8 \mu \mathrm{s}$ の CIGRE 波と同等の $Z_{r}$ を与える $\mathrm{RAMP}$ 波の波頭長を外括す ると約 $4 \mu \mathrm{s}$ となる。すなわち, 電流 $50 \mathrm{kAk}$ に対応す るRAMP 波の波頭長は $4 \mu$ s とすべきところを文献 (10)は $50 \mathrm{kA} \div 30 \mathrm{kA} / \mu \mathrm{s} \fallingdotseq 1.6 \mu \mathrm{s}$ と想定していること になる。しゅん度を過大愦嗮すれば，それを使って計 算した逆フラッシオーバ発生率は瀜大になるはずであ るが, USAに扔いては超高圧以上の送電線の大部分 は水平配列一回線送電線であり，鉄塔高さが低いこと と, 鉄塔上半部の構造が 2 脚になっているために垂直 二回線配列鉄塔に比へて鉄塔インピーダンスの影響が 小さく，重故実續と計算值との間に顕著な差が出る要 因となっていない可能性が大きい。

文献 (9)は，上記の文献(10)の結果を引用し波頭長 $2 \mu$ を適切であるとしている。

\section{7. 結言}

著者らの論旨を要約すれば次のとおりである。

(1) 鉄塔逆フラッシオーバの予測計算に採用して いる仮定中に，EMTPで正確に解明できる事項があ る。日本に扔ては，架空地線上の落雷の全数の $1 / 3$ 〜1/4 が鉄塔頂に集中落雷して残り $(2 / 3 \sim 3 / 4)$ は鉄塔 
逆フラッシオーバに関与しないと仮定している計算例 が多いが，これは半々のほうが適切である。

また，USAでは雷撃電流波頭部の最大しゅん度 $\left(S_{m}\right)$ と同一しゅん度の RAMP 波を使って逆フラッシ オーバを解析すれば実用上十分であるとしている計算 方式があるが，規約波頭長に対応するしゅん度 $S_{30}$ (波高值の $30 \%$ と $90 \%$ の点を結ぶ直線のしゅん度)の (1〜1.4)倍を採用することが適切である。図 10 から, 雷撃電流 50〜 $100 \mathrm{kA}$ の範囲では, $S_{m}$ は (4〜 4.8) $S_{30}$ である。従って， $S_{m}$ と同一しゅん度の RAMP 波を 使うことは (4〜 4.8)/(1〜1.4), すなわち 2.5〜4 倍過 大なしゅん度の RAMP 波を使ったことに相当する。

(2) 著者らは, EMTPを使用して，日本の 500 $\mathrm{kV}$ および $275 \mathrm{kV}$ 垂直二回線配列送電線の事故率を 解析した結果, 雷撃電流を RAMP 波で代表させたと きには 70 150 kA で波頭長を約 $4 \mu \mathrm{s}$ と仮定すれば計 算值が実績と整合することがわかった。

（3）最近の独立高塔頂に扔ける雷撃電流実測結

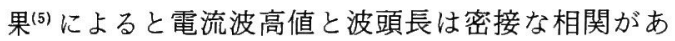
り，雷電流值が大きくなるほど波頭長が長くなること を示している。275〜 $500 \mathrm{kV}$ 送電線に逆フラッシオー バを発生させるに足る電流は $70 \mathrm{kA}$ 以上で，このよ うな大電流領域の波頭長は上記の実測によれば数 $\mu \mathrm{s}$ 以上の長波頭である。これらの独立高鉄塔頂の実測結 果から見ても, 平均波頭長を $2 \mu \mathrm{s}$ 程度と仮定してい る解析法(1) (3)(9)(10) 1 見直すべきものと考える。

（4）雷撃電流は各種の波頭長のものが混在するの で, 全数を平均的な单波頭長で代表させるよりは多数 の代表的な波頭長の集合として取扱うほうが合理的で あることはいうまでもない(15)。また雷撃電流波頭長 は波高值と密接な相関があるので, 波高值の範囲を多 数に区分してその区分ごとに波頭長を論ずるべきであ る。電流の大小にかかわらず全雷撃を一括して統計処 理すると, 小さい電流に特有の短い波頭長が, 大きい電 流のときにも起こりうるというような，あり得ない組み 合せを取込んだ計算をすることになる恐れがある(17)。

本論文に引用した資料は, 電力中央研究所送配電部 鈴木俊男部長, 井上敦之専門役, 佐々木三郎 絶縁研 究室長, 同所塩原実験場 岸嶋 勇場長, 同所赤城試 験センター 青島好英課長そのほか多数の方々から頂 載した。銘記して厚くお礼を申し上げる。

(平成元年 7 月 11 日受付, 同 2 年 5 月 8 日再受付)

\section{文 献}

（1）耐雷設計基準委員会: 「送電線耐雷設計基準要網」, 電力中 研報告, 71037(昭 46)
（2）耐雷設計基盤委員会：「送電線耐雷設計ガイドブック」, 同 上, 175031 (昭 51)

（3）井上：「送電線雷害事故率予測計算法」, 同上, T 87089 (昭 63)

(4) AIEE Committee: "A Method of Estimating Lightning Performance", AIEE Trans. Power Apparatus Syst., PAS $-69,1187(1950)$

(5) K. Berger, R. Anderson: \& "H. Kröninger; "Parameters of Lightning Flashes", Electra, No.41, 23(1975)

(6) R. Anderson \& A. Eriksson; "Lightning Parameters for Engineering Application", ibid., No.69, 65(1980)

（7）雷害事故調查委員会：「15 箇年 (昭和 40-54 年度)の送電線 雷害事故の集計」, 電力中研委員会報告, 18002,36 (昭 56)

（8）耐雷技術委員会：「送電線雷害事故統計(昭和 $55 \sim 59$ 年 度) 」, 同上, T 86803(昭 62)

(9) IEEE-WG: "A simplified method for estimating lightning performance", IEEE Trans, Power Apparatus Syst., PAS104, 919 (1985)

(10) J. J. La Forest, et al.: "Transmission Line Reference Book p.552 (1982) Elec. Power Research Inst.

（11）沢田・鈴木, 他：「187 kV〜1000 kV の交流送電線の電気 的設計ガイドブック」，電力中研総合報告， T 02，65(昭 61)

(12) 岸嶋・熊谷：「鉄塔逆フラッシオーバの事故様相に関する実 験」, 電力中研研究報告, 177066 (昭 53)

（13）井上：「複道体架空送電線路における高電圧進行波の減衰変 わい特性」，電学論 B，97，757 (昭 52-12)

(14) 電力系統のサージ解析調査専門委：電力系統における雷サ一 ジ解析の新手法」，電気学会技報(II部)，No.244(昭 62)

(15) J. Clayton, \& F. Young :"Estimating Lightning Performance of Transmission Lines", AIEE Trans. Power Apparatus Syst., PAS-83, 1102 (1964)

（16）川合：「送電線の不平衡絶縁の設計指針」, 電力中研報告, 電力 63014,34 (昭 38)

(17) J. G. Anderson : "Monte Carlo Computer Calculation of Transmission Lines", AIEE Trans. Power Apparatus Syst. PAS-80, 414(1961)

（18）松原, 他：「500 kV 新いわ線の雷サージ特性」, 電力中研 依頼報告, T 88503 (昭 63)

（19）絶縁設計合理化専門委：「絶緑設計の合理化」, 央気協同研 究, 44, No. 33,26 (昭 63)

(20) 日本 EMTP 委員会 : Electro Magnetic Transmission Program Theory Book (昭 62)

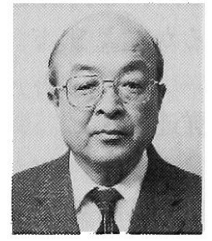

\section{有 働 龍 夫（正員）}

大正 14 年 9 月 15 日生。昭和 24 年 3 月東京大学第二工学部電気工学 科卒業。電力中央研究所において高 電圧試験, 送電線路絶緑の研究に従 事。同所電力技術研究所長, 理事を経て現在は特別顧 問。工学博士。 57 年電気学会東京支部長, 41,48 , 49 年同編修理事。 44 年電力賞, $29,37,58$ 年進歩 賞, 同 39 年論文賞受賞。IEEE フェロー。

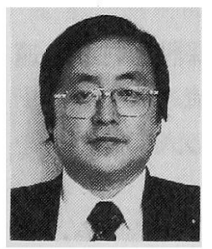

\section{松 原 廣 治（正員）}

昭和 26 年 1 月 14 日生。 46 年 3 月八戸工業高等専門学校卒業。同年 4 月 (財) 電力中央研究所入所, 現在 に至る。主として, 電力系統の過電 圧解析の研究に從事。 